\title{
Nonchromosomal cytogenetic analysis of mammal somatic cells
}

\author{
O. A. Kovalova, N. A. Bezdeneznykh, Y. I. Kudryavets \\ R. E. Kavetsky Institute of Experimental Pathology, Oncology and Radiobiology \\ NAS of Ukraine \\ 45, Vasylkivska Str., Kyiv, Ukraine, 03022 \\ strukov2002@mail.ru
}

\begin{abstract}
The mutational events that take place in mammalian somatic cells influenced with different endogenous and exogenous factors are presented in this review. The nonchromosomal method of research allows taking into account the complex cell characteristics without time-consuming analysis of the chromosomes as such. As a result, the information can be obtained about the mitotic (phases of mitosis, the number of nuclei per cell, micronuclei, pathology of mitosis) and vital (mitotic index, apoptosis) cell statuses, as well as about the state of chromosomal integrity (the presence of nucleoplasmic bridges, nucleus protrusions, chromosome fragmentation, micronuclei). Depending on the material studied (erythrocytes and lymphocytes of peripheral blood, buccal cells, permanent cell lines etc.), a complex of cytogenetic characteristics can be selected for each case which is the most informative for determination of the mutational spectra in mammalian somatic cells.
\end{abstract}

Keywords: mutagenesis, somatic cells, cytogenetic analysis, pathology.

The study of the impact of environmental factors on the genetic apparatus of mammals is one of the main problems of ecological genetics. The chromosomal apparatus is very sensitive to any impact, from electric devices and viral infections to environmental pollution. Enhanced cytogenetic instability may cause infertility and oncological diseases. Currently the evaluation of somatic mutagenesis is the most feasible and promising approach to the formation of groups with high carcinogenic risk. Traditionally the mutation process in human somatic cells is evaluated by the method of accounting chromosomal aberrations, which are a common indicator of various mutagenic effects, however their estimate requires high professionalism of the researcher and is time-consuming.

Non-chromosomal method of studying the "cytome" presupposes the possibility of determining the frequency of micronuclei, the level of cell death and mitotic dysfunction $[1,2]$. A cytome is a combination of

(C) Institute of Molecular Biology and Genetics, NAS of Ukraine, 2013 cell properties, including its vital (necrosis, apoptosis) and mitotic (micronuclei, metaphases, anaphases, oneand binuclearity) statuses as well as the state of chromosomal integrity (the presence of micronuclei, nucleosome bridges, nuclear buds, distribution of chromosomal specific signals). This review presents different variants of cytogenetic disorders, which may be considered during the estimation of genetic welfare of people under the effect of unfavorable environmental factors, including the industrial production. Naturally, depending on the tissue under investigation (erythrocytes and lymphocytes of peripheral blood, buccal epithelium cells, etc.) the researcher can select cytogenetic properties, which are the most informative for each specific case.

This information may be also useful for cytogeneticists, working at permanent cell cultures.

Mitosis pathologies. There are scientific literature data about three criteria to detect disorders in mitotic activity in soma: 1) on-going division; 2) anaphase multipolarity and 3) change in DNA content. Each 
event can be traced by the light microscopy methods [3]. The process of mitotic division of cells is very sensitive to the effect of various factors. The emerging pathological mitoses include the fragmentation of chromosomes, chromatid bridges, chromosome delay in metakinesis, chromosome delay while diverging to poles, dispersion of hyperspiralized chromosomes, multipolar mitoses, and hollow metaphases.

The fragmentation and pulverization of chromosomes is the main form of mitotic death of the cell, which is identified by the total cytogenetic analysis (Fig. 1, see the insert - all the cellular lines, used in the experiments, were received from the Cell bank of lines from human and animal tissues of R. E. Kavetsky Institute of Experimental Pathology, Oncology and Radiobiology, NAS of Ukraine). The differences of this pathology from apoptosis were shown in various researches, including biochemical studies [4].

Morphologically this pathology can be divided in at least three groups: early fragmentation of chromosomes, when several chromosomes are destroyed; medium stage of cleavage, when a considerable amount of chromosomes is fragmented; late stage of cleavage, when all or most chromosomes are fragmented. Taking this into consideration, one might assume that chromosome fragmentation is a progressive process of gradual degradation of chromosomes [4]. During the pulverization chromosomes are broken into very small fragments; most of them lack kinetochore and thus remain immovable. The capability of inducing the pulverization of chromosomes is inherent to viruses of measles, mumps, avian cholera, Newcastle disease, adenovirus type 12, herpes simplex and tick-borne encephalitis [5]. The incubation of cell culture HeLa and Lu-106 with H3-thymidine revealed that the pulverization occurs at S-stage of the cell cycle. The chromosomes, which passed the replication period at the moment of viral effect, do not undergo pulverization [6]. There are scientific literature data, presupposing that the pulverization is a consequence of local condensation of chromosomes. Stenman and Saksela [7] suppose that it would be more reasonable to call the pulverization process "early condensation of chromosomes".

In other cases of mitosis pathology the fusion of two damaged chromosomes gives rise to a dicentric chromosome. Under the effect of both mitotic centers the chromosome is stretched between them, forming a bridge, which influences the final stages of mitosis and delays cytotomy (Fig. 2).

The chromosome arrest during metakinesis and divergence to poles occur when the kinetochore and/or cleavage spindle is damaged (Fig. 3).

Mitosis arrest at the metaphase stage is the most frequent. It occurs due to the changes in the cleavage spindle. Many substances, blocking mitosis,such as cytostatics colchicine and colcemid, hinder the polimerization of tubulins. As a result, new microtubules of the spindle are not formed, and ready ones are completely pulled apart. The mitotic chromosomes gather in the center of the cell, but they do not form a metaphase plate, instead, they are randomly located (K-mitosis).

The same consequences are due to the effect of ATP synthesis inhibitors (nitrophenol, oligomycin) and a number of poisonous substances (mercaptoethanol) on the cell. If this effect is short-term, it is possible to restore the microtubules of the spindle and cell division. At moderate effects the cells may survive and enter the following cell cycle without mitosis. In this case the non-diverged chromosomes decondense a new nuclear envelope and a new tetraploid nucleus is formed.

Thus, polyploid cells are formed under the effect of colchicine. The restoration of normal mitosis after its blocking by colchicine is related to additional stages of protein synthesis (reforming the microtubules of the cleavage spindle). Probably, the activity of the reforming processes and the formation of microtubules during the restoration depend on the degree of their demolition and the character of the damaging agent [8]. The random dispersion of hyperspiralized chromosomes in the metaphase is considered as one of $\mathrm{K}$-mitosis kinds.

Pluripolar mitoses belong to the anomalies of cell division. Here a spindle with three or four poles is formed in the metaphase instead of a bipolar spindle. This anomaly is conditioned by disorders in the functions of centrioles: a diplosome is cleaved into two active monocentrioles. These changes may be spontaneous (which is remarkable for tumor cells) or result from the effect of different inhibitors of mitotic division. The mentioned anomalous multipolar mitotic figures (Fig. 4 , see the insert) are capable of entering the anaphase and participating in the divergence of chromosome to the poles, which may cause cytotomy with the 
formation of three, four and more cells. In these cases there is no even distribution of chromosomes, but the formed cells contain random and reduced sets of chromosomes. Usually the formed aneuploid cells perish fast.

The figures, presented in Fig. 4, testify to both the cleavage of the spindle (centrioles) and disorders in some spindle fibers or chromosome centromeres due to which some chromosomes do not enter the formed groups.

The multipolar mitosis may be viewed in two ways: either as a way to decrease the ploidy of the cell population in normal conditions (during the controlled distribution of chromosome sets) [9] or as a reason of enhancing the aneuploidy, for instance, tumor cells (with no control over distribution of chromosome sets) [10]. Therefore, the study of regularities of the formation of the multipolar mitotic apparatus is of both common biological and practical relevance.

The anomalies of mitotic division may be defined by the disorders in cytotomy at the occurrence of binuclear and multinucleate cells, which is related to the inhibition of the formation of actin microfilaments, participating in the creation of cell constriction at the end of the telophase (Fig. 5, see the insert).

The hollow metaphase resembles the ring of chromosomes, which gather into the metaphase plate, locating along the cell periphery (Fig. 6, see the insert).

There are frequent combined forms of mitosis pathology (for instance, pluripolar mitoses with chromosome arrest or bridges, etc.) (Fig. 7, see the insert).

The pathological mitoses result in mutations, chromosome aberrations, which are very important for neoplastic transformation of cells. While in normal tissues the pathological mitoses are present in $2-3 \%$ of cells, in tumor cells they occur in $30-46 \%$ of cells. It was determined that the more expressed the morphological anaplasia of tumor cells and the higher the mitotic activity of cells, the more frequent the pathological mitoses.

Multinucleate cells and amitosis. Multinucleate cells are registered at pathological processes, conditioning the development of many diseases [11, 12]. The elaboration of promising methods of diagnostics and correction of diseases depends on the understanding of the mechanisms of the multinucleate cells formation and their relation to the factors forming a basis of the pathological process. Multinucleates are formed via the realization of four mechanisms: as a result of the fusion of mononuclear cells [13], the blockade of cytokinesis [14], after multipolar mitoses [15], and in case of amitotic nuclear fission [16].

Contrary to the first three well-studied mechanisms the amitosis is rarely an object of the investigation and the information volume regarding this issue is quite narrow. Amitosis was detected in the cells of different origin [17-19], in intact cells, cultivated in vitro [18] and in tumor cells [19]. It is quite relevant for the formation of multinucleate cells [16] and it is a staged process [20] with the progression of nuclear extension, karyolemma invagination and the constriction of the nucleus into parts [21] (Fig. 8).

Although the volume of reliable information about molecular and subcellular mechanisms of amitosis is insufficient, there are some data on the participation of the cellular center in the realization of this process. It is also known that if the nuclei are segmented under the effect of microfilaments and microtubules, the role of cytoskeleton elements is possible in the amitotic division as well.

There are also scientific data, proving that nonmitotic nuclear fission is a process, due to which the cells lose excessively amplified DNA and these defects of cells result in the formation of micronuclei [22] (Fig. 9 , see the insert).

The fundamental significance of amitosis in the realization of intracellular processes is proven by the fact of its presence in many types of cells and in different conditions. As the role of amitotic division of polyploid nuclei in the formation of polynucleates is considered well-proven, the essence of amitosis is the establishment of optimal nuclear-cytoplasmic relations, which allow the cells to perform different functions adequately [16].

Multinuclear test. In the early 1970s Heddle and Schmidt independently suggested the multinuclear test based on the quantity of micronuclei in polychromatophilic erythrocytes of bone marrow [23, 24]. Initially it was elaborated for erythroid cells of the bone marrow, but later it was applied to the estimation of micronuclei in early spermatids and fetal liver while studying the transplacental activity of the chemical 
Figures to article by O. A. Kovalova et al.
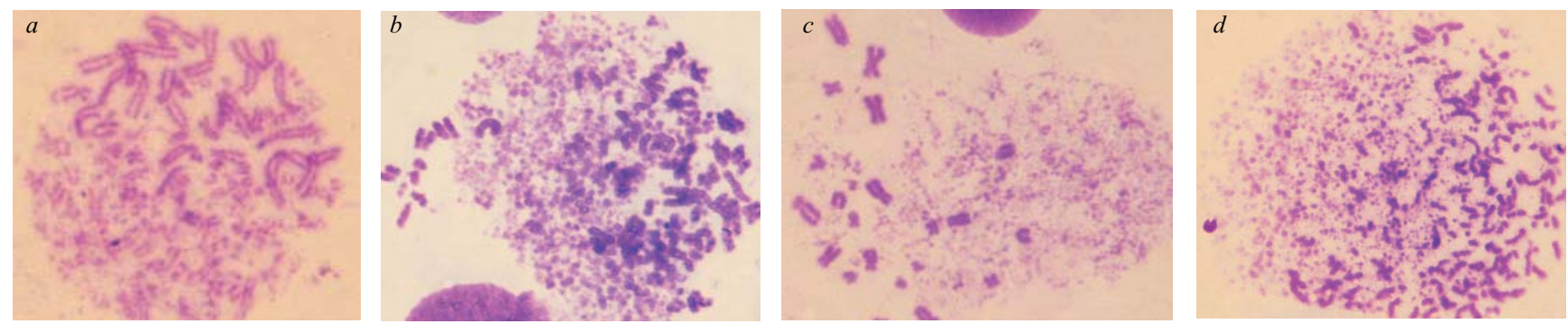

Fig. 1 Different variants of chromosome fragmentation and pulverization: $a, b$-medium stage of breakage (fragmentation); $c, d$-late stage of breakage with fine fragments - pulverization. Cell line K562 (chronic human myeloid leukemia). $\times 1000$

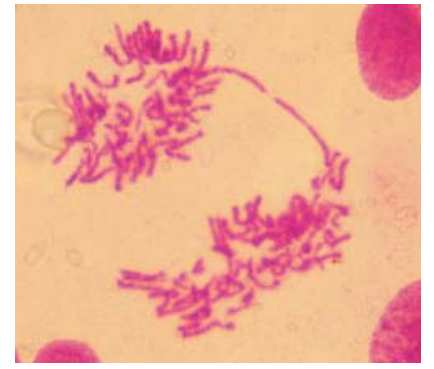

Fig. 2 Chromatid bridges. Cell line A-549 (human lung carcinoma). $\times 1000$
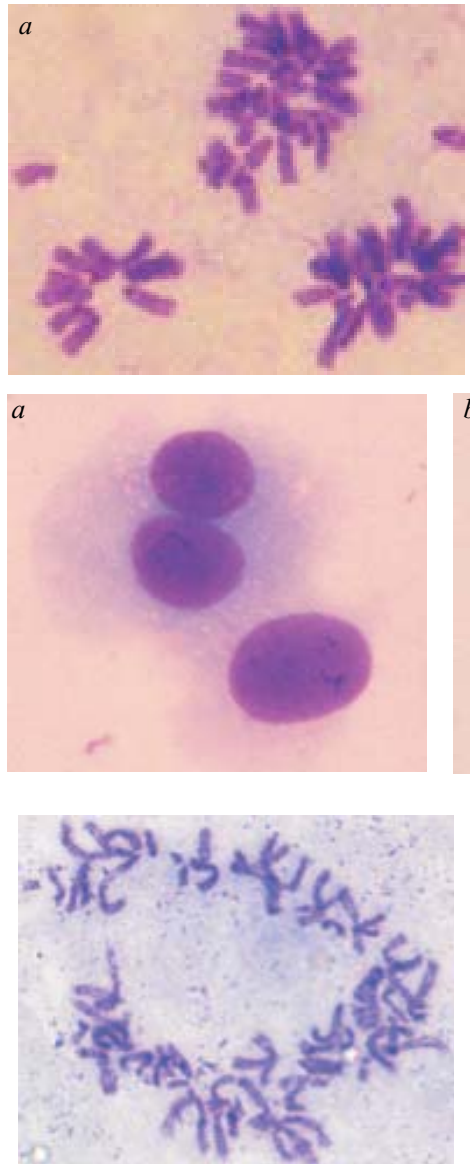
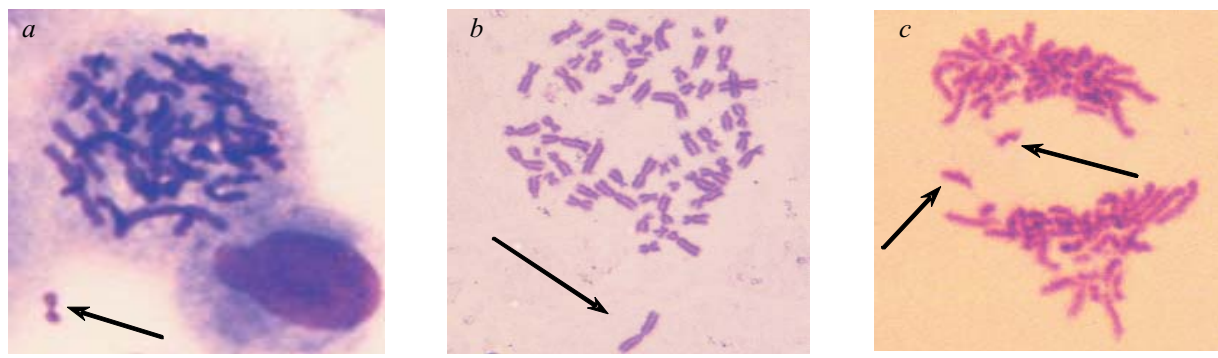

Fig. 3 Chromosome lagging in metaphase $(a$ - cell line A-549; $b$ - cell line Du-145 - human prostate cancer) and in anaphase $(c-$ cell line MCS - rat breast cancer). $\times 1000$
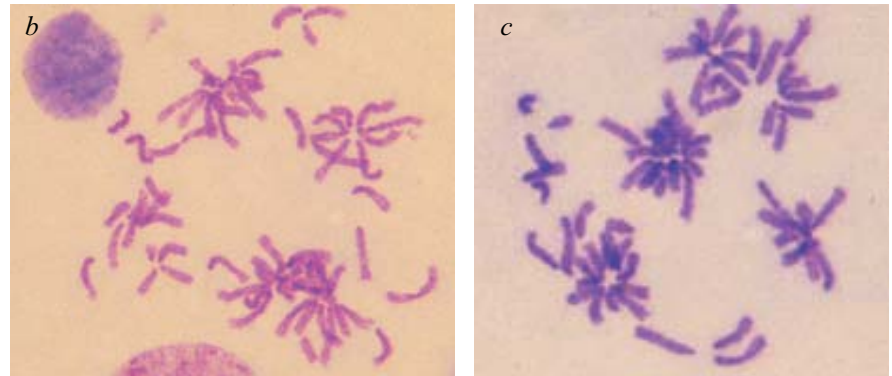

Fig. 4 Pluripolar mitotic figures: $a-$ a three-group figure; $b, c-$ multigroup figures. Cell line CMS-180, isolated from the tumor strain S-180 - spontaneous mice carcinoma $\times 1000$
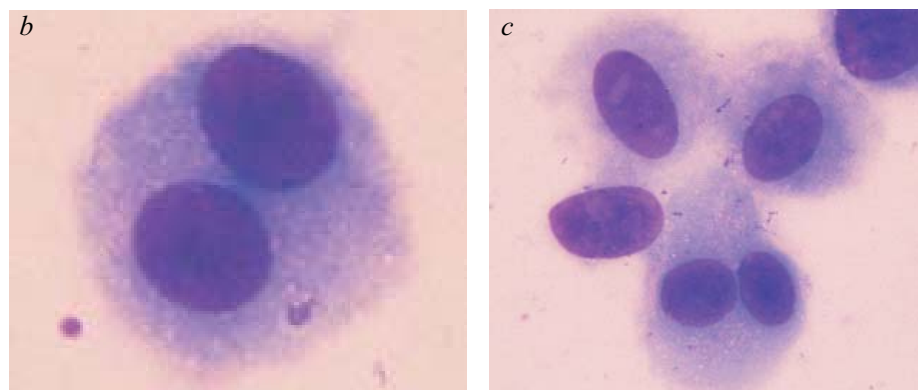

Fig. 5 Binuclear cells: $a, c-$ without a micronucleus; $b$ with a micronucleus. Cell line A-549. $\times 1000$

Fig. 6 Hollow metaphase. Cell line A-549. $\times 1000$

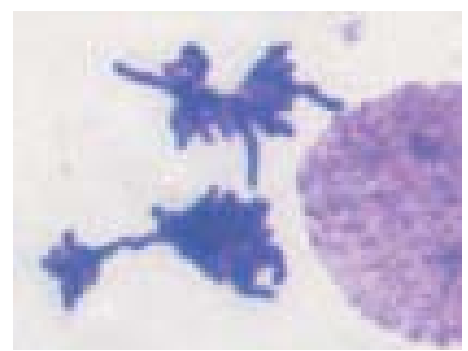

Fig. 7 Pluripolar mitosis with chromatid bridge. Cell line MCS

$\times 1000$ 
compounds, in mucous cells of the mouth, human lymphocytes, the cells of animal liver and large intestines. At present the estimation of micronuclei is possible in the majority of populations of dividing cells. It was demonstrated that the multinucleate test, being as sensitive as the test of detecting the chromosome aberrations in the cells of animal bone marrow, at the same time is less time-consuming.

The micronuclei are formed in the process of cell divisions out of lagging acentric fragments, which occurred during the chromosome breaking (clastogenic effect), and lagging chromosomes (aneugenic effect). The micronuclei can also be formed due to non-mitotic extrusion of chromatin from interphase nucleus [22]. They do not have a nuclear membrane, yet they are capable of lysis or can be included into the nucleus during the following mitosis [5] (Fig. 10).

The micronuclear test is a common cytogenetic method of estimating the mutagenic effect of various agents. It was used to test the mutagenic activity of a great number of chemical, physical and biological agents [25-27], thus this test is applied at the first stage of detecting potential mutagens and carcinogens. Its advantages are quickness of investigation regardless of the karyotype of the species, which is often remarkable for a number of small and poorly observable chromosomes, and reliability as well as the possibility of testing in tissues with low mitotic activity. The micronuclear analysis is performed in the embryo cells, in spermatids, and ootids which is especially important in the prognosis of consequences for the progeny.

The use of the micronuclear test in exfoliated cells is the most sensitive and fast method of determining the effect of mutagen/carcinogen as well as antimutagen/ anticarcinogen on human organism in vivo [28]. The study of buccal epithelium cells is the most convenient method of estimating the cytogenetic anomalies for people, living on unfavorable territories or working in hazardous industries [29].

The analysis of micronuclei in polychromatophilic erythrocytes is less common, but very informative nonetheless [26]. For instance, the increase in the number of erythrocytes with micronuclei in peripheral blood in patients with atopic asthma is in direct proportion to the degree of disease severity. The formation of micronuclei may be related to the increase in the level of endomutagenesis in the organism of patients and is likely to play a specific role in the regulation of apoptosis [25].

In recent decades the micronuclear test in peripheral blood lymphocytes (PBL) was used to estimate the effect of genotoxic agents on humans. The conceptual basis of this approach was the hypothesis that genetic disorders in PBL reflect critical events for carcinogenic processes in target tissues [30]. According to the data of Koliubaeva [31] the micronuclear test is reasonable in determining the level of radiation for large groups of people in the dose up to $1 \mathrm{~Gy}$. The application of cells with three or more nuclei as an indicator may become an additional evidence to the radiation effect as these anomaly forms are not registered in healthy people.

Besides, the estimation of micronuclei in human PBL is widely used as a biomarker of oncological risk. High frequency of cells with micronuclei is associated with the presence of different oncological diseases, including the diseases of urogenital and gastrointestinal systems [27, 32].

The micronuclear test in binucleate cells. The analysis of binucleate cytokinesis-blocked lymphocytes is a common practice of determining genetic disorders with the possibility of estimating the frequency of micronuclei, the level of cell death and mitotic dysfunction $[1,33]$.

Initially the method was developed to estimate the frequency of micronuclei, however it was simultaneously applied for the evaluation of chromosome bridges, nuclear anomalies, necrotic, apoptotic and dividing cells. Chromosome bridges originate from dicentric chromosomes, where centromeres are located on opposite poles of the cell in anaphase, their presence testifies to chromosomal restructuring or telomere associations. The damage of the chromosome bridge leads to the formation of micronuclei.

The hybridization with fluorescent DNA-probes on binucleate cells helps in the estimation of the frequency of aneugenic events - non-divergence and lagging of specific chromosomes [2]. The need of detecting aneugenic component of the impact arises from colossal mutagenic potential of aneuploidy as a genetic disorder, which plays a key role in malignant transformation of cells and clonal evolution of neoplasia [34]. 
Figures to article by $O$. A. Kovalova et al.
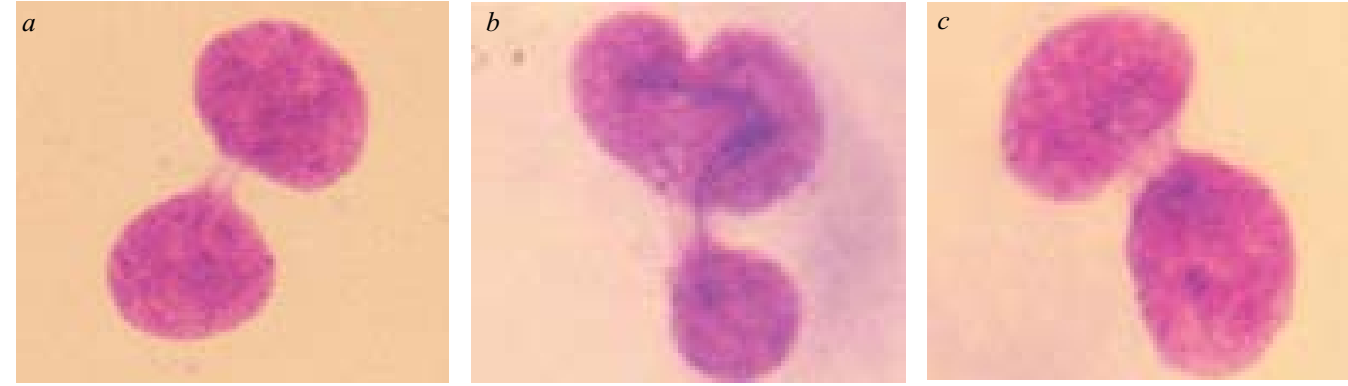

Fig. 8 Amitosis with the formation of an internuclear bridge: $a, c-$ nuclei with different divergence degree; $b-$ a nucleus with the initial stage of forming the second bridge. Cell line A-549.
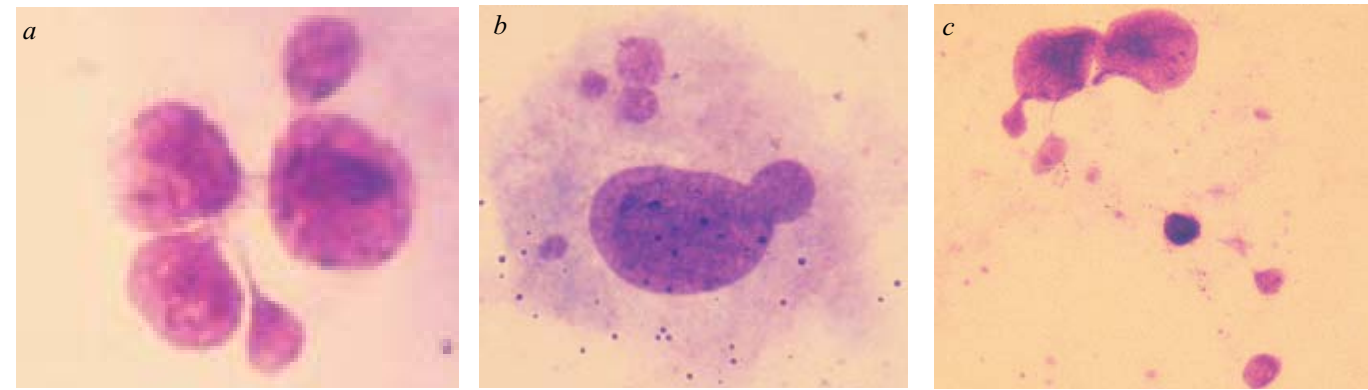

Fig. 9 Amitosis with the formation of micronuclei: $a, b$ - cell A-549; $c$ - cell line MCS. $\times 1000$
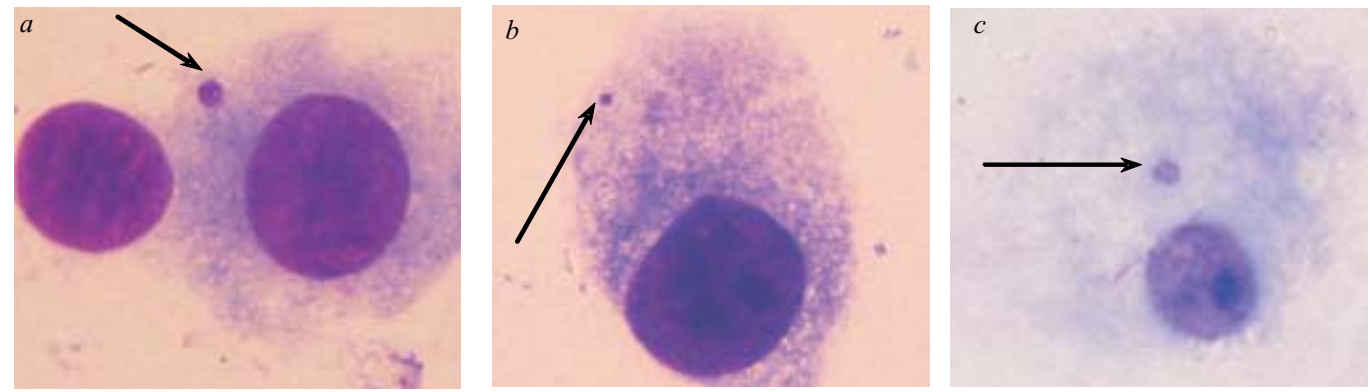

Fig. 10 Micronuclei in mononuclear cells: $a, b-$ cell A-549; $c$ - cell line MCS. $\times 1000$
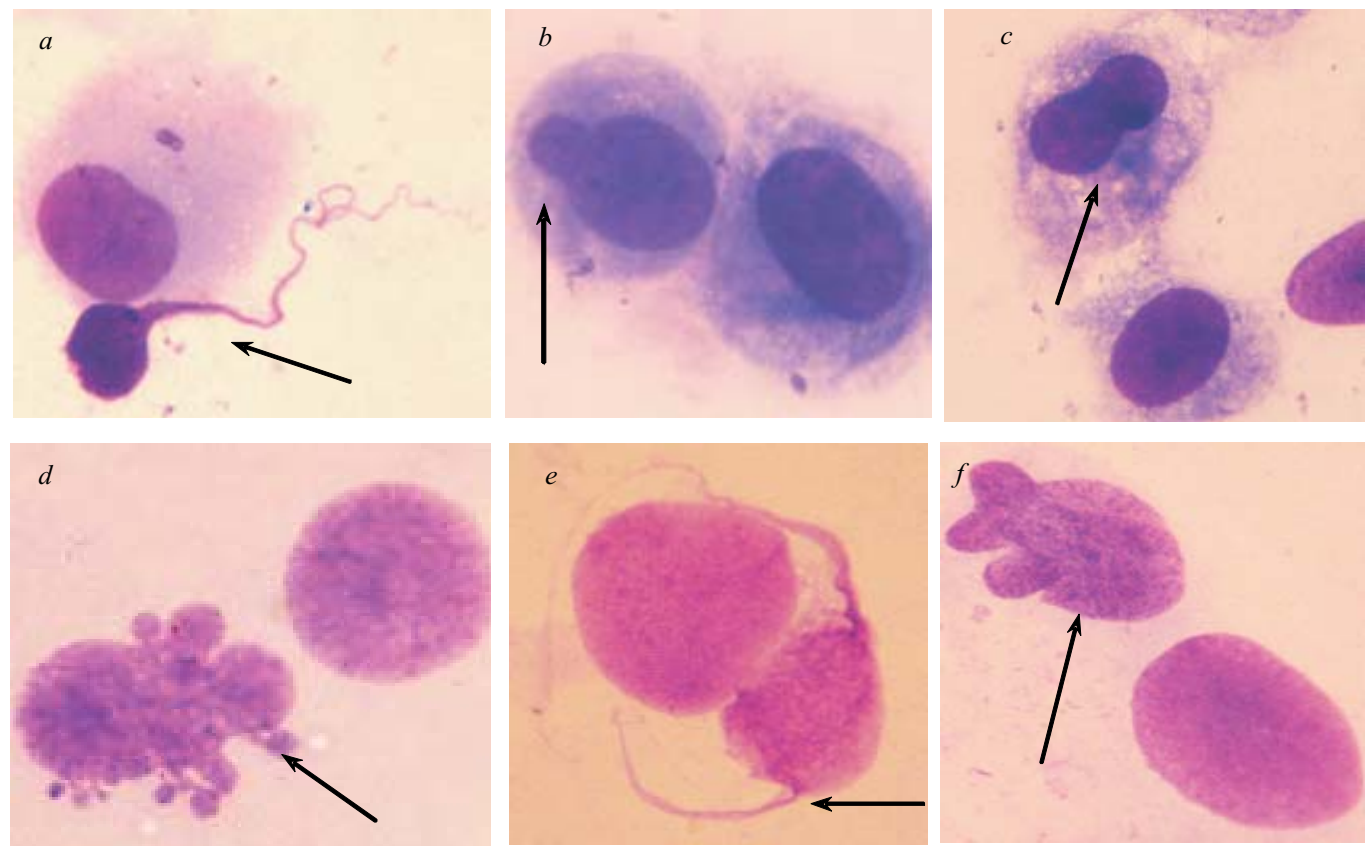

Fig. 11 Different nuclear protrusions (indicated by arrows): $a$ - "tailed" nucleus; $b$ - nuclear bud; c - binary nucleus; $d-$ multiple protrusions; $e$ - nucleus with two "tails"; $f$ - nucleus with several buds. Cell line A-549. $\times 1000$ 
The micronuclear analysis in cytokinesis-blocked cells is a comprehensive test used to estimate all the cells, including necrotic and apoptotic ones, as well as the number of nuclei per cell in order to detect cytotoxic and mitotic activity [1].

Usually, the estimation of micronuclei is conducted along with the calculation of morphological changes in the nucleus structure - all kinds of nuclei of neither round nor oval form, which contain various blades and "bulging", so called nuclear protrusions.

Nuclear anomalies. Nuclear protrusions, including broken eggs, nucleoplasmic bridges, nucleus buds, are the DNA-containing formations, located in the cytoplasm outside of the nucleus, having a spherical, fiberlike or other shape, distinctly separated from the nucleus and linked to it via a bridge. Nuclei of atypical form are in the cells with a binary nucleus (cells with two non-diverged nuclei). They are also called nuclei with constriction, nuclei with incision.

Among morphological nuclear anomalies noteworthy are the nuclei with protrusions into cytoplasm area, so called "tailed" nuclei [35] (Fig. 11)

The main mechanism of atypical nuclei and protrusions occurrence may be not clastogenic, but rather aneugenic effect of toxic agents, related to the damage of proteins of the cell division spindle [36]. The binary nuclei may be formed due to incomplete mitosis [37].

Nuclear anomalies are likely to indicate both degenerative processes in cells, where they are observed, and the fact of preceding chromosome aberrations, which formed them. For instance, the main pool of dicentric chromosomes in human lymphocytes, radiated in vitro and cultivated with cytochalasin $\mathrm{B}$, is transformed into dumb-bell nuclei [38]. The occurrence of cells with specific morphological anomalies of nuclei may be related to ring chromosomes, which are reliable cytogenetic markers of radiation [35, 39].

Different nuclear protrusions are also associated with the mechanisms of cell disposal from excessively amplified DNA. The amplification of genes is known as the stage of progression of tumor processes in the cell [39].

The cells with abnormally changed nuclei are also formed due to the effect of ionizing radiation on cell populations [38], which are associated with radial pathomorphosis in clinical cytology [40]. The increa- sed occurrence of cells with nuclear protrusions in lymphocytes of people, living on the radionuclide-polluted territories, is considered to be a negative cytogenetic indicator [41].

Premature chromosome condensation. The chromosome condensation in mammals is closely related to the impairment of nuclear envelope in early prophase of mitosis with the formation of the division spindle. In some cases this condensation occurs prior to cells entering mitosis. This phenomenon was called premature chromosome condensation (PCC) (Fig. 12).

PCC was first described in 1970 by Johnson and Rao, who used the method of intercellular fusion [42]. They demonstrated that PCC occurs when one of fused cells enters mitosis. Initially this event was related to the application of UV-inactivated Sendai virus [42], later the methods of cell fusion using such chemical substances as polyethylene glycol were elaborated [43].

In case of PCC the chromosomes may be of different morphology, which determines the stage of cell induction. According to Stevens [44], at PCC in $\mathrm{G}_{2}$-phase the chromosomes are morphologically close to normal mitotic chromosomes with sister chromatids and without any gaps, although their chromatids are longer than those of metaphase chromosomes, i.e. like those of chromosomes at the start of the prophase. At PCC in G1-phase the untriggered replication of DNA resulted in the presence of non-sister chromatids. In S-phase the premature condensed chromosomes look like condensed parts of chromatin, there are also chromosomes with multiple gaps, the number of which depends on the degree of DNA replication [45].

Premature condensation of a limited number of chromosomes may also result from the presence of multinucleate cells with asynchronous replication [44].

High frequency of spontaneous PCC, typical for tumor cells, is related to the defect of the "reference point" at $\mathrm{G}_{2} / \mathrm{M}$ stage of the cell cycle (dysfunction of P53 protein, accumulation of cyclin B1, activation of cdc2 - cyclin-dependent kinase) and is one of the sources of genetic heterogeneity, immortalization and adaptation of cell populations to different conditions of chemo- and radiotherapy of tumors $[46,47]$.

This pathology of the cell cycle may cause the increase in the share of aneu- and polyploid cells, the occurrence of which is likely to support the enhanced 
Figures to article by O. A. Kovalova et al.
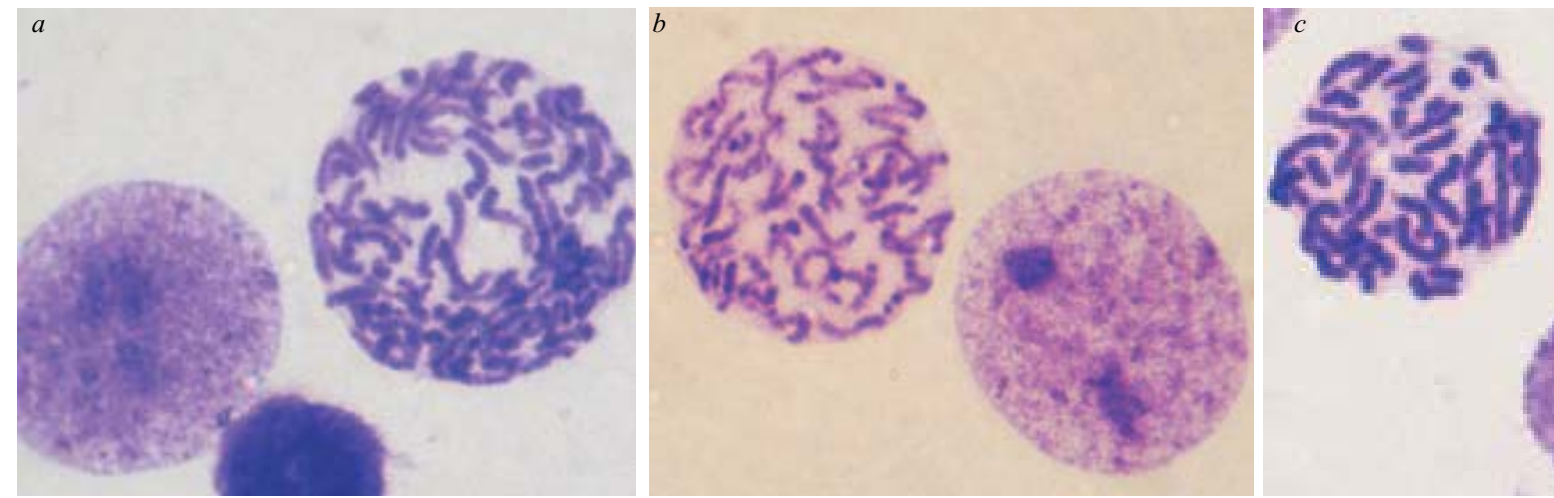

Fig. 12 Premature chromosome condensation (PCC): $a$ - polyploid cell with PCC; $b$-initial stage of condensation; $c$ - diploid cell with PCC. Cell line MCS. $\times 1000$
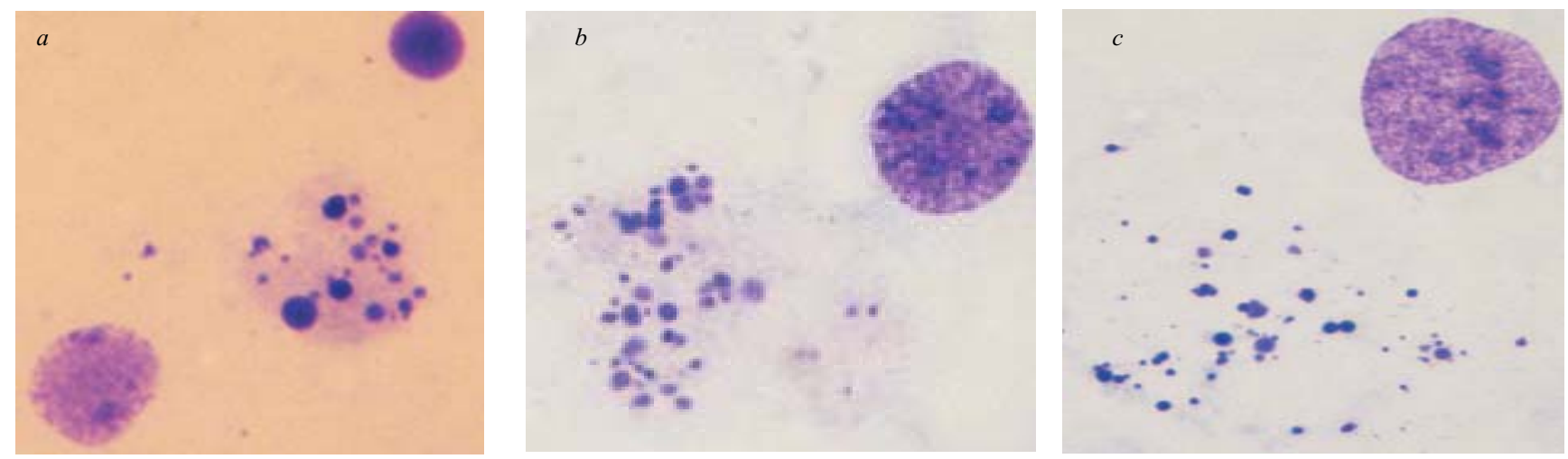

Fig. 13 Apoptosis: $a-c-$ different degrees of nucleus fission. Cell line A-549. $\times 1000$ 
malignant transformation of cells [48]. The estimation of cells with PCC may be used during the cytogenetic analysis of quiescent and senescent cells. This analysis is of great importance during the estimation of karyotypic diversity, it may be used to foresee the clinical course of various diseases, including microcephaly and mental retardation [49], and the ratio between the cells with PCC and the general pool of dividing cells may serve as an additional cytogenetic property in the evaluation of probability of genetic instability of cell populations [48].

It was determined that the increase in the frequency of interphase cells with PCC is closely related to the cell death [50]. It is assumed that PCC precedes one of the variants of cell death - "mitotic catastrophe" (MC), occurring with the participation of intracellular mechanisms, which are different from those for apoptosis [51].

Mitotic catastrophe. The mitotic catastrophe (MC) is observed as a consequence of a number of stress factors, including heat shock, chemical agents, ionizing radiation, and is remarkable for changed cell morphology [46]. PCC is an early stage of this process. Later these cells either do not survive up to cytokinesis, or divide and almost immediately fuse, thus forming figures, typical for the MC-type death. At the same time it was demonstrated that some cells endure MC and their progeny is notable for high frequency of aneuand polyploids $[46,47]$.

The notion of mitotic catastrophe was introduced to indicate the death of cells with the features of mitosis pathology. What should be called a mitotic catastrophe is under on-going discussion. Some authors believe that MC is the realization of apoptotic program in the process of mitosis proper [52]. Here there is no chromosome segregation and the cell is blocked in one of the mitosis phases. Usually the blocking occurs in so called K-mitosis (colchicine-like mitosis) when the organization of the spindle in the mitotic cell is impaired and chromosomes are lined in the form of metaphase plate. It is followed by the activation of caspases and subsequent apoptosis-related events. The mitochondrial way of the activation of apoptosis program is considered to be prevailing in the cell death during mitosis proper.

The second subtype of MC is the death of cells, which passed into the next $\mathrm{G}_{1}$-phase after abnormal mitosis without normal segregation of chromosomes and the formation of daughter cells [53], i.e. postmitotic death of polyploid cells. At general euploidy of the polyploid cells, some of their nuclei are mainly aneuploid. This MC subtype may be called the apoptosis of the cell, which passed the polyploidizing mitosis.

The reason for MC is deemed to be the change in the control process in cells with possible DNA damages or impairments of the spindle structure [52]. The key moment in the blocking of the cell cycle and apoptosis induction in these cells is the expression of protein p53, which performs the function of the transcription factor for p21 - the inhibitor of G1-phase of the cell cycle and a number of proapoptotic proteins.

Apoptosis. The cells with cytogenetic impairments are defective and may be removed from the population because of apoptosis intensification. The program of apoptotic death consists of the following main stages:

1) induction of apoptosis program;

2) activation of proapoptotic proteins;

3) cascade of caspases, splitting target proteins;

4) destruction of intracellular organelles or their restructuring;

5) cell fragmentation into apoptotic bodies;

6) preparation of the cell and its fragments to phagocytosis by macrophages or neighboring cells.

Apoptosis launch involves various organelles, first and foremost the plasmatic membrane and mitochondria.

The induction of apoptosis and proapoptotic proteins is activated by caspases (cysteine proteases). There are initiator and effector caspases, functioning as proteolytic cascades. The effector caspases induce the destruction of most proteins, participating in the homeostasis maintenance and reparation of cell components, proteins-regulators of the cell cycle, structural proteins, etc. The activity of the effector caspases and enzymes, activated by them (endonucleases, gelsolin, etc.), results in the demolition of intracellular lamina, impairment of DNA integrity, specific compaction of chromatin, breaking the elements of cytoskeleton, mitochondria, Golgi apparatus, endoplasmatic reticulum, etc. In addition to the caspase mechanism, there is a non-caspase mechanism of apoptotic death, which is remarkable for the yield of flavoprotein AIF and endonuclease $\mathrm{G}$ from mitochondria and their migration 
into the nucleus, causing the splitting of DNA into large fragments. There is observed condensation of chromatin and exposition of phosphatidyl serine in the outer monolayer of the plasmatic membrane [54].

The morphological transformations in the apoptosis process are expressed by different degrees of intracellular components breakdown. The final stages of apoptosis are thickening of the cytoplasm, fragmentation of nuclei and cells with the formation of apoptotic bodies, containing nuclei fragments, elements of Golgi apparatus, mitochondria, etc. (Fig. 13).

The frequency of apoptotic cells may not be the only indicator and adequate criterion of genotoxic effects, as it is controlled by the whole assembly of genes along with tissue-specific activity of macrophage cell elements, eliminating apoptotic cells.

Therefore, the study of the cytome provides for comprehensive estimation of the state of cell population. Such aneugenic events as the damage of the proteins of cell division spindle and the impairment of cytotomy are proven by the increase in the frequency of cells with micronuclei (if micronuclei were formed by lagging chromosomes), with different nuclear protrusions, amitotic nuclei, two or more nuclei, as well as pluripolar mitoses. Clastogenic impairments are expressed by the formation of micronuclei (for chromosome breakdown), chromatid and/or chromosome bridges. Irreversible events - the changes in the control processes in the cell with damaged DNA or impairment of the spindle structure - lead to programmed cell death. Non-chromosome analysis allows detecting the complex of cytogenetic characteristics in somatic mammalian cells, which is the most informative for any specific case.

\section{О. А. Ковалева, Н. А. Безденежных, Ю. И. Кудрявеи}

Нехромосомный цитогенетический анализ соматических клеток млекопитающих

Институт экспериментальной патологии, онкологии и радиобиологии им. Р. Е. Кавецкого НАН Украины

Ул. Васильковская, 45, Киев, Украина, 03022

\section{Summary}

В обзоре рассмотрены мутационные события, происходящие в соматических клетках млекопитающих под влиянием различных эндо- и экзогенных факторов. Нехромосомный метод исследова ния позволяет учитывать совокупность характеристик клетки без трудоемкого анализа непосредственно самих хромосом. В результате получают информачию о митотическом (фазы мито- за, количество ядер на клетку, микроядра, патологии митоза) $u$ витальном (митотический индекс, апоптоз) статусах клетки, а также о состоянии целостности хромосом (наличие нуклеоплазматических мостов, ядерных протрузий, фрагментации хромосом, микроядер). В зависимости от изучаемого материала (эритроциты и лимфоциты периферической крови, клетки буккального эпителия, постоянные клеточные линии и т. п.) можно выбрать комплекс ичитогенетических характеристик, наиболее информативный в каждом отдельном случае для определения мутационных спектров в соматических клетках млекопитаюųux.

Ключевые слова: мутагенез, соматическая клетка, иитогенетический анализ, патология.

\section{О. А. Ковальова, Н. О. Бездєнєжних, Ю. Й. Кудрявець}

Нехромосомний цитогенетичний аналіз соматичних клітин ссавців Резюме

В огляді розглянуто мутаційні подї, які відбуваються в соматичних клітинах ссавців під впливом різних ендо- та екзогенних факторів. Нехромосомний метод дослідження дозволяє враховувати сукупність характеристик клітини без трудомісткого аналізу безпосередньо самих хромосом. У результаті можна отримати інформацію про мітотичний (фази мітозу, кількість ядер на клітину, мікроядра, патології мітозу) і вітальний (мітотичний індекс, апоптоз) статуси клітини, а також про стан иілісності хромосом (наявність нуклеоплазматичних мостів, ядерних протрузій, фрагментаиії хромосом, мікроядер). Залежно від досліджуваного матеріалу (еритроцити $і$ лімфоцити периферійної крові, клітини букального епітелію, постійні клітинні лінії тошо) можна обрати комплекс ичитогенетичних характеристик, які найінформативнішими для кожного окремого випадку при виявленні мутаційних спектрів у соматичних клітинах ссавців.

Ключові слова: мутагенез, соматична клітина, иитогенетичний аналіз, патологія.

\section{REFERENCES}

1. Fenech $M$. Cytokinesis-block micronucleus assay evolves into a «cytome» assay of chromosomal instability, mitotic dysfunction and cell death // Mutat. Res.-2006.-600, N 1-2.-P. 58-66.

2. Timoshevsky V. A, Lebedev I. N., Vasiliev S. A., Sukhanova N. N., Yakovleva Y. S., Torkhova N. B., Puzyrev V. P. Chromosomal and cytomal analysis of somatic cell in workers of radiochemical industry with incorporated ${ }^{239} \mathrm{Pu} / /$ Radiation Biology. Radioecology.-2010.-50, N 6.-P. 672-680.

3. Steinbeck R. G. Pathologic mitoses and pathology of mitosis in tumorigenesis // Eur. J. Histochem.-2001.-45, N 4.-P. 311-318.

4. Stevens J. B., Liu G., Bremer S. W., Ye K. J., Xu W., Xu J., Sun Y., Wu G. S., Savasan S., Krawetz S. A., Ye C. J., Heng H. H. Mitotic cell death by chromosome fragmentation // Cancer Res.2007.-67, N 16.-P. 7686-7694.

5. Ilyinskikh N. N., Novitsky V. V., Vanchugova N. N., Ilyinskikh I. $N$. Micronucleus test and cytogenetic unstability.-Tomsk: Univ. press, 1992.-272 p.

6. O’Neill F. J., Miles C. P. Origin of nuclei in spontaneous HeLa cell chromosome pulverization // J. Natl Cancer Inst.-1971.-46, N 5.-P. 1085-1092.

7. Stenman S., Saksela E. The relationship of Sendai virus-induced chromosome pulverization to cell cyclus in HeLa cells // Hereditas.-1971.-69, N 1.-P. 1-14. 
8. Alov I. A., Aspiz M. E., Zapara O. M. Mechanism of reversibility of colchicine mitosis induced by colcemid // Bull. Exp. Biol. Med.-1976.-82, N 7.-P. 874-876.

9. Goyanes-Villaescusa V. Cycles of reduplication in megakaryocyte nuclei // Cell Prolif.-1969.-2, N 2.-P. 165-168.

10. Pan H., Zhou F., Gao S. J. Kaposi's sarcoma-associated herpesvirus induction of chromosome instability in primary human endothelial cells // Cancer Res.-2004.-64, N 12.-P. 4064-4068.

11. Paoli J., Smedh M., Wennberg A. M., Ericson M. B. Multiphoton laser scanning microscopy on non-melanoma skin cancer: morphologic features for future non-invasive diagnostics // J. Invest. Dermatol.-2008.-128, N 5.-P. 1248-1255.

12. Tashiro T., Kawakita C., Takai C., Yoshida T., Sakiyama S., Kondo $K$., Sano N. Primary pulmonary malignant peripheral nerve sheath tumor: a case report // Acta Cytol.-2007.-51, N 5.- P. 820-824.

13. Murch A. R., Grounds M. D., Marshall C. A., Papadimitriou J. M. Direct evidence that inflammatory multinucleate giant cells form by fusion // J. Pathol.-1982.-137, N 3.-P. 177-180.

14. Zhu J., Beattie E. C., Yang Y., Wang H. J., Seo J. Y., Yang L. X. Centrosome impairments and consequent cytokinesis defects are possible mechanisms of taxane drugs // Anticancer Res.-2005.25, N 3B.-P. 1919-1925.

15. Yun C., Cho H., Kim S. J., Lee J. H., ParkS. Y., Chan G. K., Cho H. $\mathrm{M}$ totic aberration coupled with centrosome amplification is induced by hepatitis B virus X oncoprotein via the Ras-mitogen-activated protein/extracellular signal-regulated kinase-mitogen-activated protein pathway// Mol. Cancer Res.-2004.-2, N 3.- P. 159-169.

16. Walen K. H. Spontaneous cell transformation: karyoplasts derived from multinucleated cells produce new cell growth in senescent human epithelial cell cultures // In Vitro Cell. Dev. Biol. Anim.-2004.-40, N 5-6.-P. 150-158.

17. Kuhn E. M., Therman E., Susman B. Amitosis and endocycles in early cultured mouse trophoblast // Placenta.-1991.-12, N 3.P. 251-261.

18. Arkhipov S. A., Shkurupiy V. A., Ijine D. A., Ignatovich N. V., Akhromenko E. S., Arkhipova $V$. V. Formation and some cytophysiological characteristics of polynuclear macrophages in primary cultures of peritoneal cells // Bull. Exp. Biol. Med.-2008.146, N 6.-P. 838-841.

19. Elias H., Fong B. B. Nuclear fragmentation in colon carcinoma cells // Hum. Pathol.- 1978.-9, N 6.-P. 679-684.

20. Chen Y. Q., Wan B. K. A study on amitosis of the nucleus of the mammalian cell. I. A study under the light and transmission electron microscope // Acta. Anat. (Basel).-1986.-127, N 1.-P. 69-76.

21. Kuhn E. M., Therman E., Susman B. Amitosis and endocycles in early cultured mouse trophoblast // Placenta.-1991.-12, N 3.P. 251-261.

22. Manskih V. N. On the questionthe about mechanism of micronuclei formation in normal conditions and under the influence of Nnitroso-N-metilkarbamid // Bull. Exp. Biol. Med.-2006.-141, N 2.-P. 217-220.

23. Schmid W. The micronucleus test // Mutat. Res.-1975.-31, N 1.P. 9-15.

24. Heddle J. A. A rapid in vivo test for chromosome damage // Mutat. Res.-1973.-18, N 2.-P. 187-190.

25. Vodunon A. S., Ponomareva N. A., Abramova Z. I. Cytogenetic changes in erythrocytes of patients with atopic bronchial asthma // Scientific notes of the Kazan State University. A series of nature science.-2008.-150, N 2.-P. 101-105.

26. Kovalova O., Kobozeva N., Burdo O., Glazko T. Micronuclei test as method of definition the seasonal alteration of cytogenetic characteristics in mammals // Rare theriofauna and its conservation. Series Proc. Theriological.-Luhansk, 2008.-Vol. 9.-P. 266-269.

27. Bonassi S., Znaor A., Ceppi M., Lando C., Chang W., Holland N., Kirch-Volders M., Zeiger E., Ban S., Barale R., Bigatti M. P.,
Bolognesi C., Cebulka-Wasilewska A., Fabianova E., Fucic A., Hagmar L., Joksic G., Martelli A., Migliore L., Mirkova E., Scarfi M. R., Zijno A., Norppa H., Fenech M. An increased micronucleus frequency in peripheral blood lymphocytes predicts the risk of cancer in humans // Carcinogenesis.-2007.-28, N 3.-P. 625-631.

28. Nersesian $A$. $K$. The micronucleus test in human exfoliative cells as a method for studying the action of mutagens/carcinogens // Tsitol. Genet.-1996.-30, N 5.-P. 91-96.

29. Rajkokila K., Shajithanoop S., Usharani M. V. Nuclear anomalies in exfoliated buccal epithelial cells of petrol station attendants in Tamilnadu, South India // J. Med. Genet. Genom.-2010.-2, N 2.P. 18-22.

30. Lando C., Hagmar L., Bonassi S. Biomarkers of cytogenetic damage in humans and risk of cancer. The European Study Group on Cytogenetic Biomarkers and Health (ESCH) // Med. Lav.1998.-89, N 2.-P. 124-131.

31. Koliubaeva S. N. Chromosomal aberrations, micronuclei and apoptosis in lymphocytes at radiation and other pathological states: dis. ... Doctor of Science: 01.03 .01 - radiobiology.- St. Petersburg, 2010.-261 p.

32. Nersesyan A. K. Possible role of the micronucleus assay in diagnostics and secondary prevention of cervix cancer: a minireview // Tsitol. Genet.-2007.-41, N 5.-P. 64-66.

33. Pejchal J., Vasilieva V., Hristozova M., Vilasova Z., Vavrova J., Alyakov M., Tichy A., Zarybnicka L., Sinkorova Z., Tambor V., Kubelkova K., Dresler J. Cytokinesis-block micronucleus (CBMN) assay/CBMN cytome assay in human lymphocytes after in vitro irradiation and its use in biodosimetry // Mil. Med. Sci. Lett. (Rev. sanitaire militaire).-2011.-80, N 1.-P. 28-37.

34. Williams B. R., Amon A. Aneuploidy: cancer's fatal flaw // Cancer Res.-2009.-69, N 13.-P. 5289-5291.

35. Nikiforov A. M., Fedortseva R. F., Monosova E. K., Iartseva N. M., Kravtsov V. Iu. Nuclei with protrusions - «tailed» nucleus and radiation cytogenetic markers in culture of lymphocytes after X-ray irradiation // Radiation Biology. Radioecology.2000.-40, N 3.- P. 299-304.

36. Sycheva L. P. Biological significance, criteria and limits of the full range of karyological variation in the evaluation of man cytogenetic status // Med. Genetics.-2007.-6, N 11.- P. 3-11.

37. Sycheva L. P., Lovacheva O. V., Stanuk T. A., Yevtushenko G. $V$., Kovalenko M. A. Cytogenetic lesions of bronchial epitheliocytes in patients with pulmonary tuberculosis // Tuberkulez i Bolezni Legkikh.-2008.-N 7.-P. 35-38.

38. Ibragimova $N$. $V$. Investigation of nuclei anomalies of somatic cells populations exposed to radiation exposure in vitro and in vivo // Dissertation of the candidate biological sciences 14.00.46.St. Petersburg, 2004.-122 p.

39. Khudoley $V$. $V$. Carcinogens: a characteristic, pattern, mechanisms of action.-St. Petersburg, 1999.-256 p.

40.Agamova K. A. Clinical cytology in the study of radiation pathomorphism of breast cancer // News of Clinical Cytology of Russia.- 1997.-2, N 2.-P. 52-58.

41. Madonova Y. B., Trofimov V. A. Morphological abnormalities of interphase nucleus in donor lymphocytes at the chronic ionizing radiation at low doses // Morphological newsletter.-2009.-N 34.-P. 52-57.

42. Johnson R. T., Rao P. N. Mammalian cell fusion: induction of premature chromosome condensation in interphase nuclei // Nature.-1970.-226, N 5247.-P. 717-722.

43. Lau Y. F., Brown R. L., Arrighi F. E. Induction of premature chromosome condensationin CHO cells fused with polyethlyene glycol // Exp. Cell Res.-1977.-110, N 1.-P. 57-61.

44. Stevens J. B., Abdallah B. Y., Regan S. M., Liu G., Bremer S. W., Ye C. J., Heng H. H. Comparison of mitotic cell death by chromosome fragmentation to premature chromosome condensation // Mol. Cytogenet.-2010.-3.-P. 20. 
45. Sperling K. Cell cycle and chromosome cycle: Morphological and functional aspects // Premature chromosome condensation application in basic, clinical and mutation research / Eds P. Rao, R. Johnson, K. Sperling.-New York: Acad. press Inc., 1982.-P. 43-75.

46.Ianzini F., Bertoldo A., Kosmacek E. A., Phillips S. L., Mackey M. A. Lack of p53 function promotes radiation-induced mitotic catastrophe in mouse embryonic fibroblast cells // Cancer Cell Int.-2006.-6.-P. 11.

47. Erenpreisa J., Kalejs M., Ianzini F., Kosmacek E. A., Mackey M. A., Emzinsh D., Cragg M. S., Ivanov A., Illidge T. M. Segregation of genomes in polyploid tumour cells following mitotic catastrophe // Cell Biol. Int.-2005.-29, N 12.-P. 1005-1011.

48. Kovaleva O. A., Glazko T. T., Kochubey T. P., Lukash L. L., Kudryavets $Y$. I. Spontaneous premature condensation of chromosomes in normal and transformed mammal cells // Exp. Oncol.2007.-29, N 1.-P. 18-22.

49. Neitzel H., Neumann L. M., Schindler D., Wirges A., Tonnies H., Trimborn M., Krebsova A., Richter R., Sperling K. Premature chromosome condensation in humans associated with microcephaly and mental retardation: a novel autosomal recessive condition // Am. J. Hum. Genet.-2002.-70, N 4.-P. 1015-1022.
50. Mackey M. A., Morgan W. F., Dewey W. C. Nuclear fragmentation and premature chromosome condensation induced by heat shock in S-phase Chinese hamster ovary cells // Cancer Res.1988.-48, N. 22.-P. 6478-6483.

51. Ricci M. S., Zong W. X. Chemotherapeutic approaches for targeting cell death pathways // Oncologist.-2006.-11, N 4.-P. 342-357.

52. Castedo M., Perfettini J. L., Roumier T., Andreau K., Medema R., Kroemer $G$. Cell death by mitotic catastrophe: a molecular definition // Oncogene.-2004.-23, N 16.-P. 2825-2837.

53. Roninson I. B., Broude E. V., Chang B.D. If not apoptosis, then what? Treatment-induced senescence and mitotic catastrophe in tumor cells // Drug Resist. Updat.-2001.-4, N 5.-P. 303-313.

54. Hong Q., Hsu L. J., Schultz L., Pratt N., Mattison J., Chang N. S. Zfra affects TNF-mediated cell death by interacting with death domain protein TRADD and negatively regulates the activation of NF-kappaB, JNK1, p53 and WOX1 during stress response // BMC Mol. Biol.-2007.-8.-P. 50.

Received 12.11 .12 